DOI https://doi.org/10.30525/978-9934-588-80-8-2.51

\title{
ПРОЄКТУВАННЯ ВІРТУАЛЬНОЇ ПРАКТИЧНОЇ ПІДГОТОВКИ (VIRTUAL PRACTICЕ) МАЙБУТНІХ ПЕДАГОГІВ В УМОВАХ ЗМІШАНОГО НАВЧАННЯ (BLENDED LEARNING)
}

\author{
Чупахіна С. B. \\ кандидат педагогічних наук,
}

дочент кафедри теорії та методики дошкільної і спеціальної освіти ДВНЗ «Прикарпатський національний університет

імені Василя Стефаника»

Круль Л. О.

кандидат педагогічних наук,

доиент кафедри теорії та методики дошкільної і спеціальної освіти ДВНЗ «Прикарпатський наиіональний університет імені Василя Стефаника» м. Івано-Франківськ, Україна

Однією 3 провідних тенденцій процесу інформатизації сучасної освіти $\epsilon$ активне впровадження нових засобів і методів навчання, зорієнтованих на використання інформаційних технологій (IT). Сучасні IT вирізняються потужним освітнім потенціалом, широким спектр можливостей, дозволяють реалізувати нові форми і методи навчання, інтенсифікувати навчальний процес на всіх рівнях.

Оновлення освітніх стандартів, які забезпечують включення в освітній простір дітей з особливими потребами, зміни в системі вищої педагогічної освіти, з урахуванням компетентнісного підходу, який зосередив увагу на формуванні у майбутніх фахівців готовності до практичного застосування знань і умінь в роботі з кожною дитиною та іiі сім'єю. Компетентнісний підхід визнано як концепцію організації освітнього процесу, метою якого стає формування професійної компетентності здобувача, засобом іiі досягнення $є$ модульна побудова змісту й структури професійного навчання [2].

У педагогіці розроблено основні методологічні підходи до застосування IT в системі безперервної освіти фахівців різного профілю, однак не проводилося досліджень щодо застосування означених технологій в системі практичної підготовки майбутніх педагогів в умовах змішаного навчання, розробки та використання електронних 
інструментів формування професійної компетентності та готовності застосовувати знання в практиці роботи.

Вагомою перевагою інструментів навчання, заснованих на IT, стає моделювання діяльності людини, реальних явищ та процесів. Моделювання професійної діяльності в освітньому процесі - це таке іiі відображення в змісті освіти й в навчальній діяльності, яке, сприяє формуванню у майбутніх педагогів уявлення про цілісність професійної діяльності (від визначення мети до самоаналізу процесу й результатів діяльності) та допомагає опанувати способами (діями, операціями) повною мірою задля забезпечення швидкого включення в професійну діяльність (А. Вітченко, А. Вербицький, Б. Гершунський, С. Гончаренко, І. Дичківська, О. Дубасенюк, В Загвязинський, І. Зязюн, І. Зимня, В. Кремень, В. Луговий, Є. Лодатко, Н. Ничкало, О. Овчарук, Є. Полат, Дж. Равен, В. Свистун, С. Сисоєва, А. Хуторський, В. Ягупов, V. Devi та ін.).

Методологічний підхід до використання IT в підготовці майбутніх педагогів ініціює потребу в розробці різних типів електронних інструментів, необхідних для формування базових професійних компетентностей педагогів в умовах змішаного навчання [1].

Технологія змішаного навчання (blended learning) як система викладання, поєднує очну, дистанційну та самоосвіту, передбачає взаємодію між педагогом, здобувачами та інтерактивними джерелами інформації та відображає всі властиві освітньому процесу компоненти (мету, зміст, методи, організаційні форми, засоби навчання, що функціонують в постійній взаємодії один з одним, утворюючи єдине ціле) $[3,4]$.

Відтак виникає необхідність організації певного виду практик, спрямованих на засвоєння професійних практичних компетентностей в умовах змішаного навчання, такими практиками визнано саме віртуальні. За допомогою віртуальних практик створюються унікальні умови навчання, які важливі для послідовного відпрацювання операційного складу умінь та формуються практичні фахові компетентності, які не можуть бути створені іншими засобами. В означений спосіб відкривається можливість моделювати в аудиторії ситуації професійної діяльності та покроково формувати у здобувачів педагогічної освіти практичні компетентності й усі складові їхніх вмінь. 
Означені практики відкривають можливість моделювати в аудиторії ситуації професійної діяльності, які пов'язано з психолого-педагогічними та методичними особливостями роботи з дітьми різного віку [5].

Віртуальна практика передує виробничій практиці, надаючи можливість тренувати здобувачів у вирішенні практичних завдань на спеціально підібраних випадках роботи з дітьми.

В обраній методології вихідним етапом проєктування віртуальної практики стає аналіз предметної області, виділення та опис формованої компетентності з якої складаються результати навчання.

Визначаються також функції віртуальної практики в системі формування професійних компетентностей майбутніх педагогів.

Наступним кроком визначено принципи проєктування віртуальної практики з урахуванням функцій та місця означенного електронного інструменту в освітньому процесі ЗВО в умовах змішаного навчання.

Визначивши принципи побудови віртуальної практики, отримуємо можливість перейти до ії проєктування. Означений підхід передбачає також визначення вікової характеристики дітей, вибір методики роботи 3 дітьми, з урахуванням якої розробляється електронний інструмент.

Спеціальним завданням $є$ урахування принципів проєктування віртуальної практики, які спрямовано на засвоєння майбутніми вчителями основних аспектів та методик роботи з дітьми визначеного віку (рис. 1).

Реалізація вищеозначених принципів під час проєктування віртуальної практики забезпечує умови необхідні для формування професійних компетентностей фахівця, які не можуть бути сформовані у інший спосіб. 
виокремлення та опис компетентності і результатів навчання як її складових

виокремлення загально педагогічних, спеціальних та інформатичних компонентів професійної компетентності

узгодженого та одночасного формування загальнопедагогічних

і методичних знань і умінь

послідовного формування виокремлених знань і вмінь в структурі

практичної підготовки майбутніх педагогів

формування операційного складу кожного вміння

моделювання та відеозйомка епізодів професійної діяльності педагога, в яких

прослідковується означені і враховано послідовність кожного компонента

моделювання та відеозйомка епізодів роботи фахівця,

які демонструють коректні та помилкові дії

визначення необхідної та достатньої кількості для формування означеної компетентності відеосюжетів

моделювання та відеозйомка епізодів взаємодії дітей

розробка вимог до відеозйомки з урахуванням особливостей методики роботи та критеріїв оцінки діяльності дитини

розробки вимог до матеріалу, який відбображає різні сторони процесу роботи (поведінка дітей, коректна і помилкова поведінки педагога, способи взаємодії тощо)

визначення продуктивних видів навчальної діяльності здобувача для засвоєння кожного виду завдань

визначення необхідних та достатніх для формування запланованих професійних компетентностей типів і видів навчальних вправ

забезпечення зворотного зв'язку - надання здобувачам-практикантам інформації про якість процесу та доступу до результатів виконання навчальних завдань

надання варіативної допомоги на будь-якому етапі роботи здобувача під час віртуальної практики

\section{Рис. 1. Принципи просктування віртуальної практики}

\section{Література:}

1. Жалдак M. I. Інформатизація навчального процесу має сприяти поглибленню і розширенню бази знань - основи творчої діяльності майбутнього фахівця. Науковий часопис Національного педагогічного університету імені М. П. Драгоманова. Комп’ютерно-орієнтовані системи навчання, 2016. № 18. С. 3-6.

2. Заїка Л. А. Визначення організаційно-педагогічних умов застосування технології імітаційного моделювання. Компетентісний 
вимір сучасної освіти : теорія і практика : зб. тез V регіон. наук.-практ. конф. (м. Запоріжжя, 19 травня 2017 р.). Запоріжжя , 2017. С. 68-70.

3. Теорія та практика змішаного навчання : монографія. За ред. В. М. Кухаренка. Харків : Міськдрук, НТУ ХПІ, 2016. 284 с.

4. Чупахіна С. В. Технологія змішаного навчання в неформальній та інформальній освіті: підготовка майбутніх учителів до діяльності в умовах інклюзивного середовища початкової школи. Неформальна та інформальна освіта як ресурс розвитку особистості : матеріали Міжнародній науково-практичній конференції (м. Київ, 22 травня 2020 р.). Київ : Таврійський національний університет імені В. І. Вернадського, 2020. С. 154-158.

5. Aldrich C. Learning by Doing: A Comprehensive Guide to Simulations, Computer Games, and Pedagogy in E-Learning and Other Educational Experiences. San Francisco : Pfeiffer, A Wiley Imprint. URL: https://www.amazon.com/Learning-Doing-Comprehensive-SimulationsLearning/dp/0787977357 (дата звернення: 20.09.2020)

DOI https://doi.org/10.30525/978-9934-588-80-8-2.52

\title{
ВИКОРИСТАННЯ КРЕОЛІЗОВАНИХ ТЕКСТІВ У ПРОФЕСІЙНІЙ ПІДГОТОВЦІ МАЙБУТНІХ ФАХІВЦІВ ДЕРЖАВНОЇ КРИМІНАЛЬНО-ВИКОНАВЧОЇ СЛУЖБИ УКРАЇНИ
}

\author{
Шумейко 3. С. \\ кандидат педагогічних наук, \\ доиент кафедри педагогіки і гуманітарних дисциплін \\ Академія Державної пенітенціарної служби \\ м. Чернігів, Украӥна
}

На сучасному етапі на систему методів і засобів навчання в закладах вищої освіти суттєво впливає тотальна інформатизація суспільства, упровадження інформаційно-комунікативних технологій в освітній процес, формування кліпового мислення в молодого покоління, зростання обсягу й текстового матеріалу, необхідність його концентрації. Це детермінує необхідність відповідних трансформацій у змісті, формах і засобах організації освітнього процесу в закладах вищої освіти.

На сучасному етапі нагальною стала проблема удосконалення системи професійної підготовки майбутніх фахівців Державної 